\title{
Assessing environmental changes in abandoned German vineyards. Understanding key issues for restoration management plans
}

\author{
Jesús RODRIGO-COMINO푸, Martin NEUMANN², Alexander REMKE³ and \\ JOHANNES B. RIES 4
}

\begin{abstract}
Land degradation in vineyards is a big concern which should be considered by farmers, enterprises and policymakers. Due to intense tillage, the use of herbicides and heavy machinery, vine plantations are registering a decrease in soil fertility and, subsequently, in productivity. Recently, farmers have decided to abandon the vineyards, but any restoration planning is being carried out to recover biodiversity or to reduce soil and water losses. Nowadays, there is no information about environmental changes after the abandonment in terms of possible soil property changes and erosion in Central European vineyards such as in Germany. Therefore, the main aims of this preliminary study were to compare: i) soil properties and soil profiles of one cultivated vineyard and an abandoned one; and, ii) to assess the activation of soil erosion processes using a small portable rainfall simulator. Our results showed that the vineyard registered several differences in soil properties among slope positions and soil profile characteristics due to tillage and trampling effects, showing clear marks of compaction and soil detachment in the lower parts. Also, in this cultivated field, higher means and maxima of soil losses $\left(\mathrm{g} \mathrm{m}^{-2}\right)$ and sediment concentration $\left(\mathrm{g} \mathrm{l}^{-1}\right)$ values than in the abandoned plot were quantified, being the main driving factors the vegetation cover and the inclination. On the other hand, in the abandoned vine plantation, a rapid homogenization of soil profiles and soil properties were found along the hillslope, where a deeper organic horizon was consistently developed above a compacted and rocky horizon, which was generated during the cultivation phase. Due to the high compaction due to the machinery cultivation and the difficulties for the roots to make deep into the soil, the infiltration defaulted and the amount of runoff and runoff coefficient were higher in the abandoned plots than in the cultivated ones.
\end{abstract}

Keywords: Soil erosion, German vineyards, abandonment, rainfall simulation, soil profile

\section{Introduction}

Soil erosion is a big concern for humankind because soils provide indispensable sources and goods for living creatures and human health (Sмітн, P. et al. 2015). However, negative human impacts on soils such as the intensification of the agricultural practices are generating a drastic decrease in soil fertility and quality (Szalai, Z. et al. 2016). Therefore, to solve these kinds of problems and achieve the best solutions, the scientific community and the policymakers should collaborate with the stakeholders, actively. In this way, physical geographers have to play an important role in developing research methods and tools which are able to design sustainable land plans and feasible measures.

Techniques such as modeling (SAMAnI, A.N. et al. 2016; BALÁzs, B. et al. 2018), erosion plots (KINNELL, P.I.A. 2016) or isotopic markers (Bihari, Á. and Dezsô, Z. 2008; NovarA,

\footnotetext{
${ }^{1}$ Instituto de Geomorfologia y Suelos, Department of Geography, University of Malaga, 29071, Malaga, Spain. Physical Geography, Trier University, 54286 Trier, Germany. E-mail: rodrigo-comino@uma.es

${ }^{2}$ Czech Technical University in Prague, Faculty of Civil Engineering, Department of Landscape Water Conservation, Prague 6, Czech Republic. E-mail: martin.neumann@fsv.cvut.cz

${ }^{3}$ Physical Geography, Trier University, 54286 Trier, Germany. Diensleistungszentrum Ländlicher Raum Mosel, 54470 Bernkastel-Kues, Germany. E-mail: geo_trier@web.de

${ }^{4}$ Physical Geography, Trier University, 54286 Trier, Germany. E-mail: riesj@uni-trier.de
} 
A. et al. 2016; ЈАКАВ, G. et al. 2018) are the most common methods applied to quantify soil erosion. However, to make reproducible and comparable results of water and soil losses, rainfall simulations can be also considered a valuable tool (IsERLOH, T. et al. 2012; SzABó, J. et al. 2015).

In vineyards, the use of rainfall simulations to study initial soil erosion processes has increased because they are one of the most degraded landscapes. Rodrigo-Comino, J. et al. $(2016 \mathrm{a}, \mathrm{b})$ qualitatively assessed different viticultural areas across Europe where distinct rainfall simulations showed high soil and water losses in Campo Real (Madrid, Spain), Champagne (France), the Pènedes (Lleida, Spain) or Ruwer-Mosel valley (Trier, Germany). Also, the use of small portable rainfall simulators has been applied to investigate different specific environmental characteristics in vineyards or erosion control measures (Blavet, D. et al. 2009; Morvan, $X$. et al. 2014). However, there is another process that is also affecting the rest of the European vineyards and which has not sufficiently been investigated: land abandonment (LASANTA, T. et al. 2015).

Vineyards' soils are suffering from a high degradation as a consequence of intense tillage, the use of herbicides and heavy machinery, registering a decrease in soil fertility and, subsequently, also in productivity (CAMPS, J.O. and Ramos, M.C. 2012; García-Díaz, A. et al. 2017). Therefore, when the most fertile horizon is eliminated, vine growers decide to abandon the whole plantation. Also, as a consequence of the climate change, low lands are being abandoned, and hillslopes on the higher heights are being planted (ARNAEZ, J. et al. 2006; Galilea Salvador, I. et al. 2015). Recently, using rainfall simulations experiments (MARTínez-Hernández, C. et al. 2017), it was observed that areas where there was no vegetation recovery at all, such as in almond trees, soil loss and runoff were higher than in the cultivated areas.

In Germany, the viticultural sector is reporting high benefits for wine producers and new planting is taking place (O.I.V. 2017).
However, when a plantation is not productive or the next generation of farmers do not show any interest in vineyards, the abandonment process begins and a restoration plan should be conducted. Vegetation and biodiversity recoveries show positive benefits for both environment and humankind (BIENES, R. et al. 2016), but no incentives to carry out some kind of measures default this action.

In this way, there is no information about which environmental problems after the abandonment (e.g. soil erosion) in Central European vineyards such as in Germany could occur. We only found some precedents, for example in a study carried out in Eastern countries such as Hungary in the traditional Tokaj viticulture area, where the vegetation transformation and toposequences of the carbon storage after the abandonment and its influence on soil changes were studied (NovÁK, T.J. et al. 2014).

Therefore, the main goal of this preliminary research is to compare soils properties and initial soil erosion processes in a cultivated vineyard with an abandoned one. We pretend to show the main differences and transformations after the abandonment process in the same vineyard. To achieve this goal, soil profiles, soil analysis, and rainfall simulations were used.

\section{Materials and methods}

\section{Study area}

The localization of the two studied pairedplots can be observed in Figure 1. The selected vineyard and abandoned one are situated in the little village of Waldrach in the RuwerMoselle valley (Rhineland-Palatinate), Germany. The average elevation ranges from $200 \mathrm{~m}$ to $400 \mathrm{~m}$ a.s.l. and all are located on Devonian grauwackes, slates, and quartzites, which are in contact with Pleistocene fine materials transported by the Ruwer river, an affluent of Moselle river (RIchter, G. 1979). The vine plantation is composed of 40-years old plants and was cultivated in the summit of a 


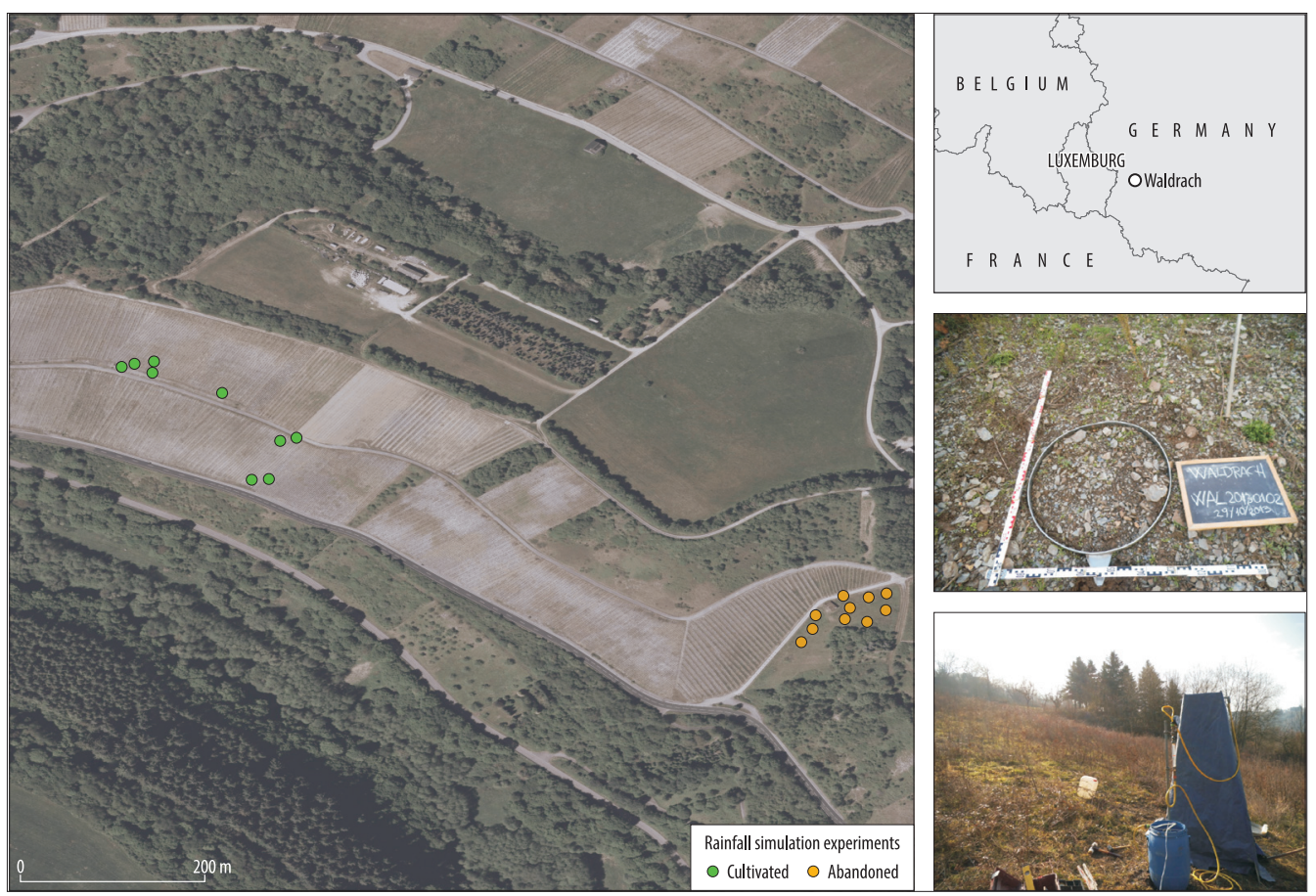

Fig. 1. Study area and rainfall simulation localization of the experiments

hillslope. On the other hand, the abandoned study plot (cultivated during 1970 with similar tillage practices to the recently cultivated one) was abandoned during 1990. In general, the hillslopes are exposed to SW direction and mean inclinations reach maximum values of $30^{\circ}$, although the studied abandoned plot shows more gentle angles $\left(15-25^{\circ}\right)$. Annual total average rainfall is about $765 \mathrm{~mm}$ and mean annual temperatures approximately $9{ }^{\circ} \mathrm{C}$ (Rodrigo-Comino, J. et al. 2015).

The grape variety is Riesling and the main soil management practices are as follows: i) tilling with machinery before and after the vintage to $20 \mathrm{~cm}$ depth (beginning of spring, and autumn); ii) the use of vine training systems with a plantation framework of $90 \mathrm{x}$ $140 \mathrm{~cm}$; iii) a high amount of slate mulch to conserve soil temperature regime; and, iv) keeping soils bare as much as possible by applying pesticides and herbicides.
In both areas, on the embankments and inter-rows, rills, landslides, and ephemeral gullies as a consequence of soil erosion can be observed. The abandoned plot is cleaned from spontaneous vegetation once in the year to prevent the recolonization close to the roads and drainages as a part of maintenance practice.

\section{Soil profile description and soil analysis}

Soil samples were collected from three different slope positions (shoulder, backslope, and footslope), at two different depths $(0-5 \mathrm{~cm}$ and $5-15 \mathrm{~cm})$ in the rows and inter-row areas. All the samples were analysed with three replicates, being a total 36 samples and amounting to about $3-4 \mathrm{~kg}$ per soil sample. First, at all, soil samples were sieved $(<2 \mathrm{~mm})$ and basic soil properties were analysed in the laborato- 
ry: Texture, total organic carbon (TOC), Calcium carbonates $(\mathrm{Ca})$, electrical conductivity (EC), pH-value and soil water content (SWC).

Texture (sand, silt, and clays) was analysed by a Coulter LS230 device, by combining different diffraction patterns of a light beam. Total organic carbon was measured by loss of ignition (LOI) and its weight difference under $430{ }^{\circ} \mathrm{C}(24 \mathrm{~h})$ in a muffle furnace (DAvies, B.E. 1974; Rosell, R.A. et al. 2001). Electrical conductivity (EC) was measured by a digital conductivity-meter and carbonates with a Bernard calcimeter. $\mathrm{pH}$-value in distilled water (1:5 proportion) using a digital $\mathrm{pH}$-meter was obtained. Soil water capacity content at field capacity and wilting point were calculated with a pressure plate extractor.

Finally, three soil profiles at different slope positions (coinciding with the soil sample places) were described to classify soil types, using the methodology designed by FAOWRB (IUSS Working Group WRB 2006, 2014).

\section{Rainfall simulations}

Nine rainfall simulations were carried out in the cultivated vineyard and fourteen in the abandoned one to compare soil loss, runoff, runoff coefficient, sediment concentration and infiltration. In Figure 1, the localisation of the experiments was mapped. We used a small nozzle-type rainfall simulator modified by RIEs, J.B. et al. (2009). This device is characterized by i) a square metal frame $(0.45 \mathrm{~m}$ x $0.45 \mathrm{~m}$ ) with a Lechler 460608 nozzle; ii) four telescopic aluminium legs in order to situate the nozzle two meters above the plot; iii) the aluminium linkage is covered by a rubber tarpaulin to eliminate wind interferences; iv) a circular test plot of $0.28 \mathrm{~m}^{2}$ with a $\mathrm{V}$-shaped outlet, which is put at the deepest point at surface level to collect the water and soil losses; v) a flow control and a $12 \mathrm{~V}$ lowpressure bilge pump that controls and make reproducible the simulated rainfall. The rainfall simulator was calibrated by IsERLOH, T. et al. (2012) for a rainfall intensity of $40 \mathrm{~mm} \mathrm{~h}^{-1}$.
Each experiment had a total duration of 30 minutes and was conducted in a randomized block at different slope positions. In five minutes' intervals (six intervals in total), water and sediments were collected in plastic bottles, which were also changed at the beginning of a new interval. Prior starting the experiments, vegetation and rock fragment covers were perceptively quantified by taking the opinion of three experts, soil roughness was assessed with the chain method (SALEH, A. 1993), slope inclination was measured with a digital clinometer and antecedent soil moisture was calculated by taking a soil sample close to the ring plot and drying at air conditions in the laboratory. The collected water with sediments in each bottle was filtrated with circular finemeshed filter papers (Munktell ${ }^{\odot}$, Prod.-Nr. 3.104.185, less than $2 \mu \mathrm{m}$ mesh-width) and, then, filters were dried to constant weight at $105{ }^{\circ} \mathrm{C}$. After that, they were weighted for determining soil loss (g) and runoff (l) for each measured interval. Final results were presented in $\mathrm{g} \mathrm{m}^{-2}$ and $1 \mathrm{~m}^{-2}$ in order to be comparable with other study areas. Also, sediment concentration $\left(\mathrm{g} \mathrm{l}^{-1}\right)$ was obtained by dividing the amount of soil loss and runoff. Runoff and infiltration coefficients were also calculated using the total area of the plot and rainfall intensity in each interval.

\section{Statistical analysis}

Descriptive statistics in boxplot graphics and tables to identify averages, maximum, minimum, median and outlier values were depicted and summarized, respectively. To compare soil properties obtained from both paired-plots (cultivated and abandoned), a nonparametric test at $\mathrm{p}>0.05$ was performed after testing the data normality (ShaphiroWilk test) and equal variance (F-test). They did not show a normal distribution. We used a Tukey test, where significant differences at $p<0.001$ level were considered.

Finally, to confirm which driving factor enhances soil erosion and makes a compari- 
son between which environmental plot characteristic and erosion result shows possible interrelationships, a Spearman's rank correlation coefficient was conducted. SigmaPlot 12.0 (Systat Software Inc.) was the software used to carry out the statistical analysis.

\section{Results and discussion}

\section{Soil analysis}

Soil analysis results showed a higher proportion of coarse gravel $(>2 \mathrm{~mm}$ ) in the cultivated plots than in the abandoned one is registered. It is important to remark that in both plots more than 34 per cent of gravels were found. The rock fragment cover is a widely studied factor in vineyards (Rodrigo-Comino, J. et al. 2017) and in other crops or environments (Nyssen, J. et al. 2001; JomAa, S. et al. 2012), because it shows a strong correlation with runoff and soil losses when it is embedded into the soil (Poesen, J.W. et al. 1998). If not, rock fragment cover uses to enhance infiltration (ZavaLA, L.M. et al. 2010) and biodiversity activity (CERTINI, G. et al. 2004). Moreover, both soils show a silty texture, but after the abandonment, a higher content of clays and fine silts can be registered. This process was also registered in other abandoned areas with schists as parent material (Martínez-Hernández, C. et al. 2017), although it appears more frequent in calcareous rocks, where a selective removal of fine particles occurs (Romero Díaz, A. et al. 2011), also affecting other soil properties such as water retention capacity and $\mathrm{pH}$ (LESSCHEN, J.P. et al. 2008; Bienes, R. et al. 2016). In our study area, this process could also be recognized. After the abandonment, increases in water retention capacity at the wilting point and at field capacity are observed. Moreover, $\mathrm{pH}$ also decreases, showing a more acidic trend, which is also an ecological indicator of soil quality registered after each land use change (Khaledian, Y. et al. 2017; Pahlavan-Rad, M.R. and Akbarimoghaddam, A. 2018). Statistical analysis proved that soil tex- ture, organic carbon, carbonate, soil water retention capacity and $\mathrm{pH}$ show a significant difference among cultivated and abandoned plots, confirming the changes in soil properties after the abandonment (Table 1).

\section{Soil profile descriptions and qualitatively assessment}

In Figure 2 and 3, soil profiles described at different slope positions also show differences among each other and after the abandonment process. In Suppl. Material, the description of all soil profiles is included to observe more in detail these differences.

As we can observe in the cultivated plot (Figure 2), soil profiles in the shoulder and backslope positions are characterized by a thin organo-mineral soil horizon (nearly $2 \mathrm{~cm}$ deep) with high alteration induced by tillage and compaction. This horizon can be signed as Ap. Underneath, a tilled soil horizon, which could be considered as $\mathrm{Ap}_{2}$, has deeper mineral soil horizons $(B / C)$. The horizon boundaries in Ap and $\mathrm{B} / \mathrm{C}$ are abrupt $(2-5 \mathrm{~cm})$ and nearly plane in the compacted layers, and irregular in the rocky layer. Soil structure grade ranges from moderate to weak, with prismatic and crumb forms. However, in the footslope, one unique horizon can be described which is characterized by clear marks of compaction. Moreover, the surface horizon is removed as a consequence of the depletion, which was also confirmed by Rodrigo-Comino, J. et al. (2016b) using the stock unearthing method and topsoil level change maps. It is widely known in studies about connectivity processes that soil depth variations among slope positions can be linked to the fact of the mass movement processes, registering in the upper part erosion, in the middle erosion-deposition (transition) and, finally, in the lower part sedimentation (LópezVicente, M. et. al. 2015; Novara, A. et al. 2016; Rodrigo-Comino, J. et al. 2016a, b; Ben-Salem, N. et al. 2018). However, in tilled vineyards, the redistribution of materials (Follain, S. et al. 2012; Quiquerez, A. et al. 2014), tractor passes (Biddoccu, M. et al. 2017) and extreme 


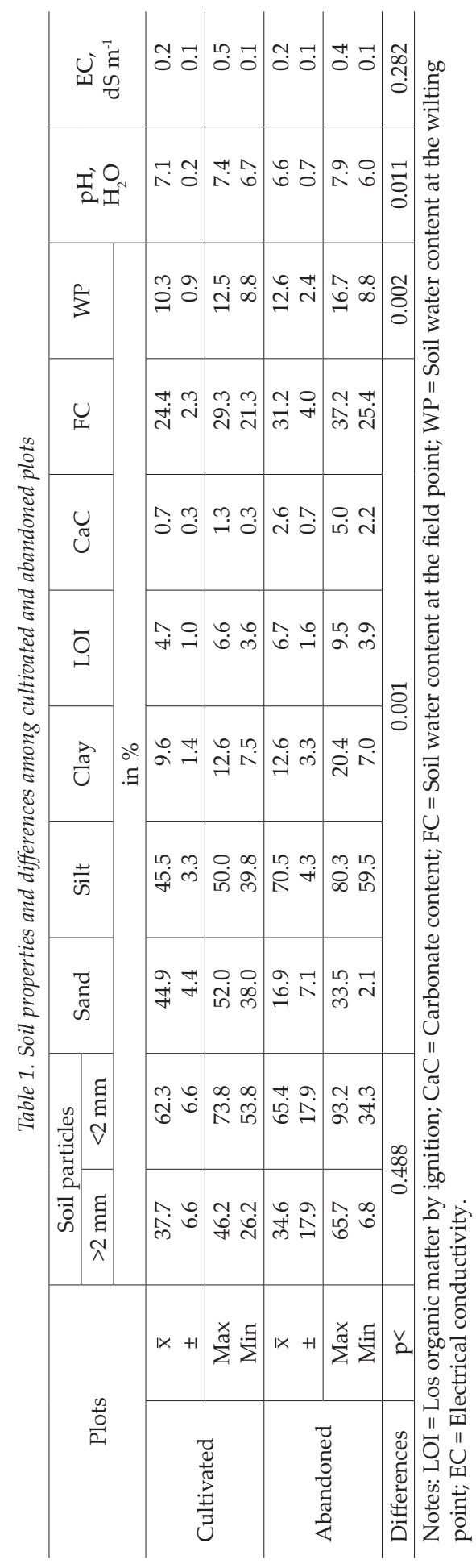

rainfall events (MARTínez-CASASNOvas, J.A. et al. 2003; De Santisteban, L.M. et al. 2006) make difficult to predict topsoil level changes along the hillslope.

In the abandoned vine plantation (Figure 3), soil profiles are characterized by 0 to $4 \mathrm{~cm}$ deeprooted organic soil horizons (litter horizon $\mathrm{O}$ ), where there are no rests of any Ap horizon and soil aggregates are similarly absent. The boundaries with underlying soil horizons are also abrupt. Underneath, we find a $\mathrm{B} / \mathrm{C}$ horizon characterized by tilled and compacted mineral features. High rock fragment contents are noted in this layer with a weak soil structure characterized by prismatic and crumb forms of 20-50 mm size. Several authors confirmed that the recuperation of abandoned soils in semiarid and arid areas need long periods (Romero Díaz, A. et al. 2011; Kou, M. et al. 2016); however, in two decades we observe that Central European vineyards are able to generate a consistent A horizon relatively fast; although the compaction marks stay there yet.

Finally, these soils can be classified as Leptic-Humic Regosols according to the FAO/ WRB soil classification (IUSS Working Group WRB, 2014).

\section{Initial soil erosion processes}

Rainfall simulation results can be observed in Table 2 and 3, where soil erosion results and environmental plot characteristics inside the ring plot are summarized, confirming high differences among plots. In Figure 4, mean, median, maximum, minimum values and outliers of measured soil erosion in both plots are depicted in box plots.

The most important differences inside the ring plots are found for vegetation cover and roughness, being higher in the abandoned plot than in the cultivated vineyard ( $97 \%$ vs $45 \%$; $1.3 \mathrm{~mm} \mathrm{~mm}^{-1}$ vs $1.05 \mathrm{~mm} \mathrm{~mm}^{-1}$ ). On the other hand, rock fragment covers and slope grades are higher in the cultivated vineyard than in the abandoned plot, reaching average values of $58,28,17$ and 5 per cent, respectively. 


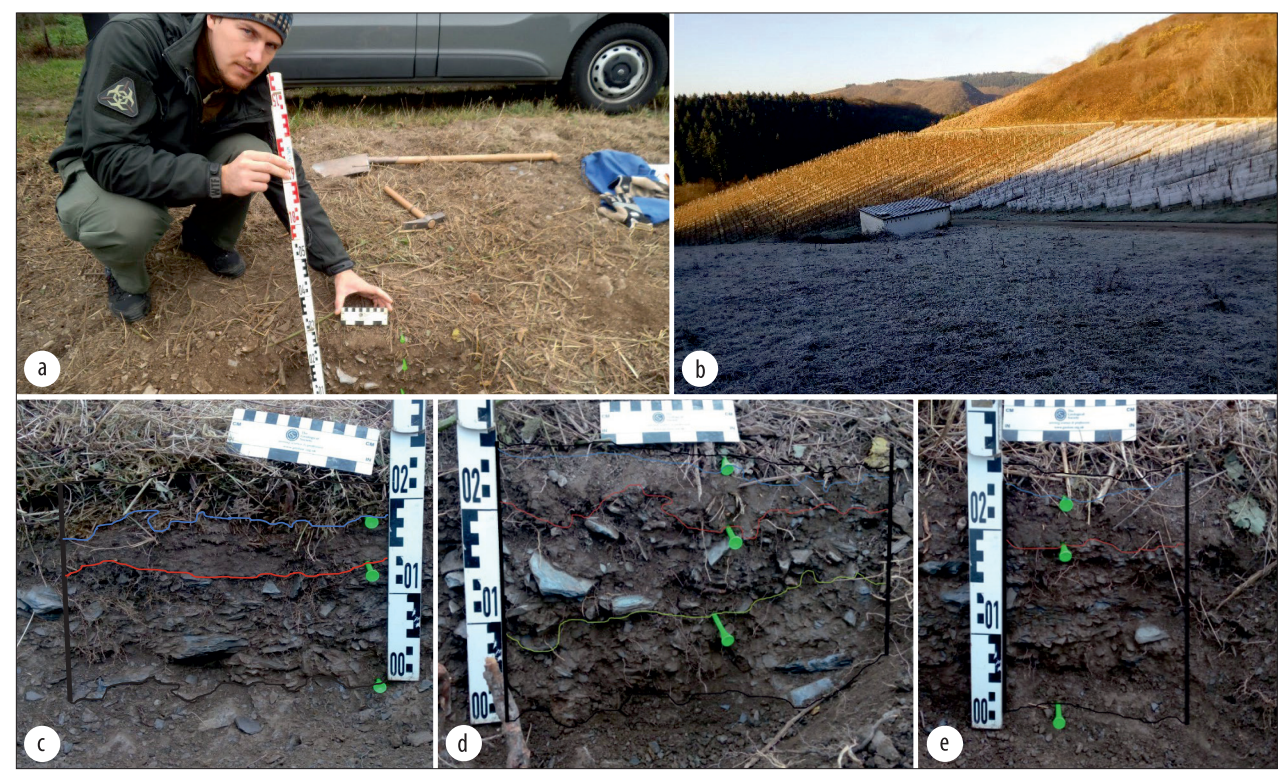

Fig. 2. Soil profiles in the cultivated plot. $-\mathrm{a}=$ soil profile elaboration; $\mathrm{b}=\mathrm{a}$ general perspective of the plot; $\mathrm{c}=$ shoulder $\mathrm{d}$ = backslope; $\mathrm{e}=$ footslope

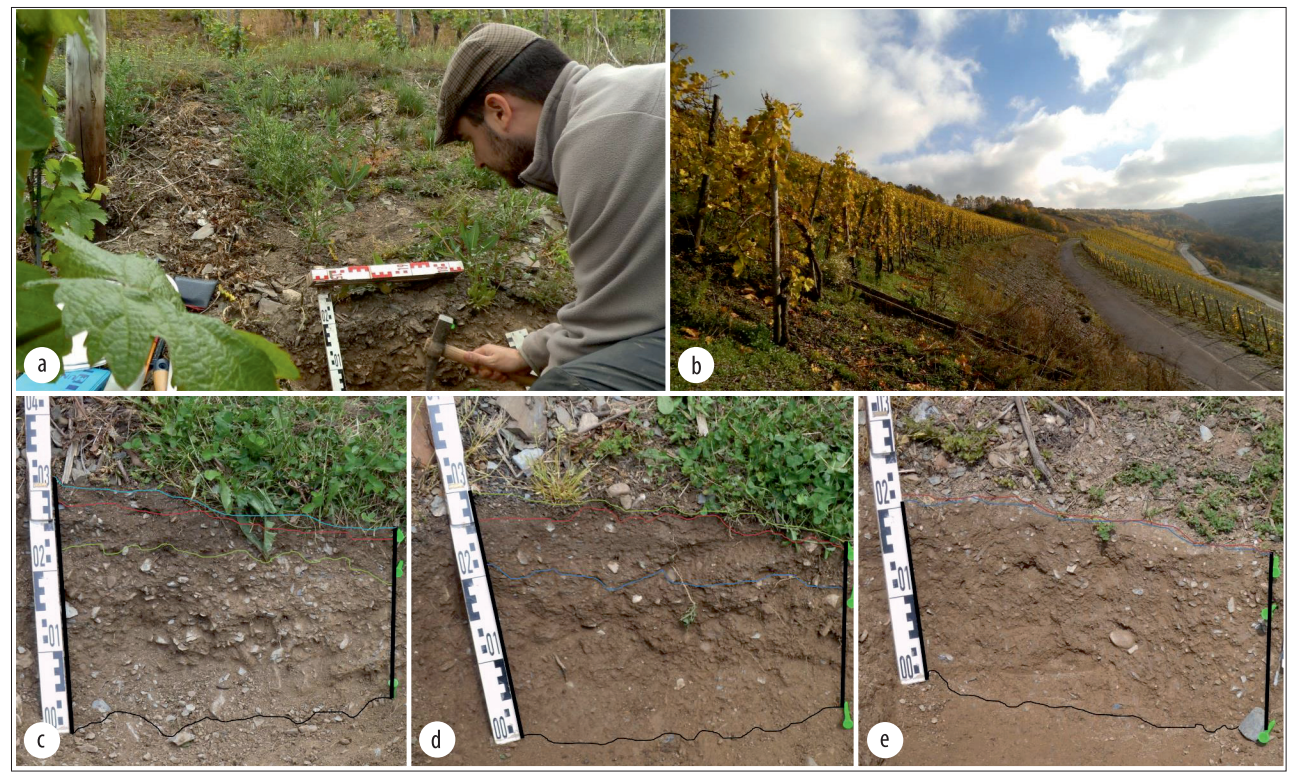

Fig. 3. Soil profiles in the abandoned plot. $-\mathrm{a}-\mathrm{e}=$ For explanation see Fig. 2. 

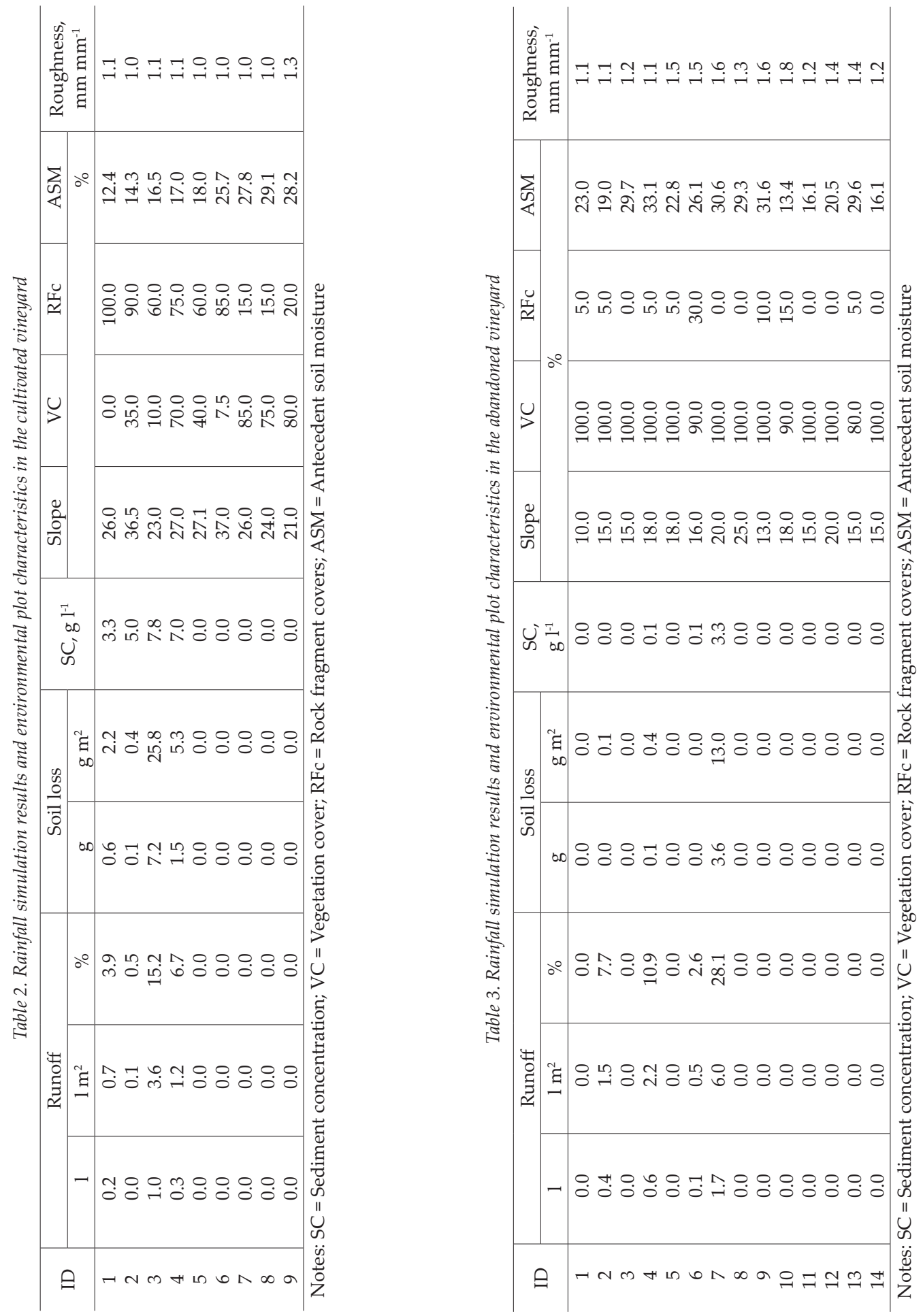


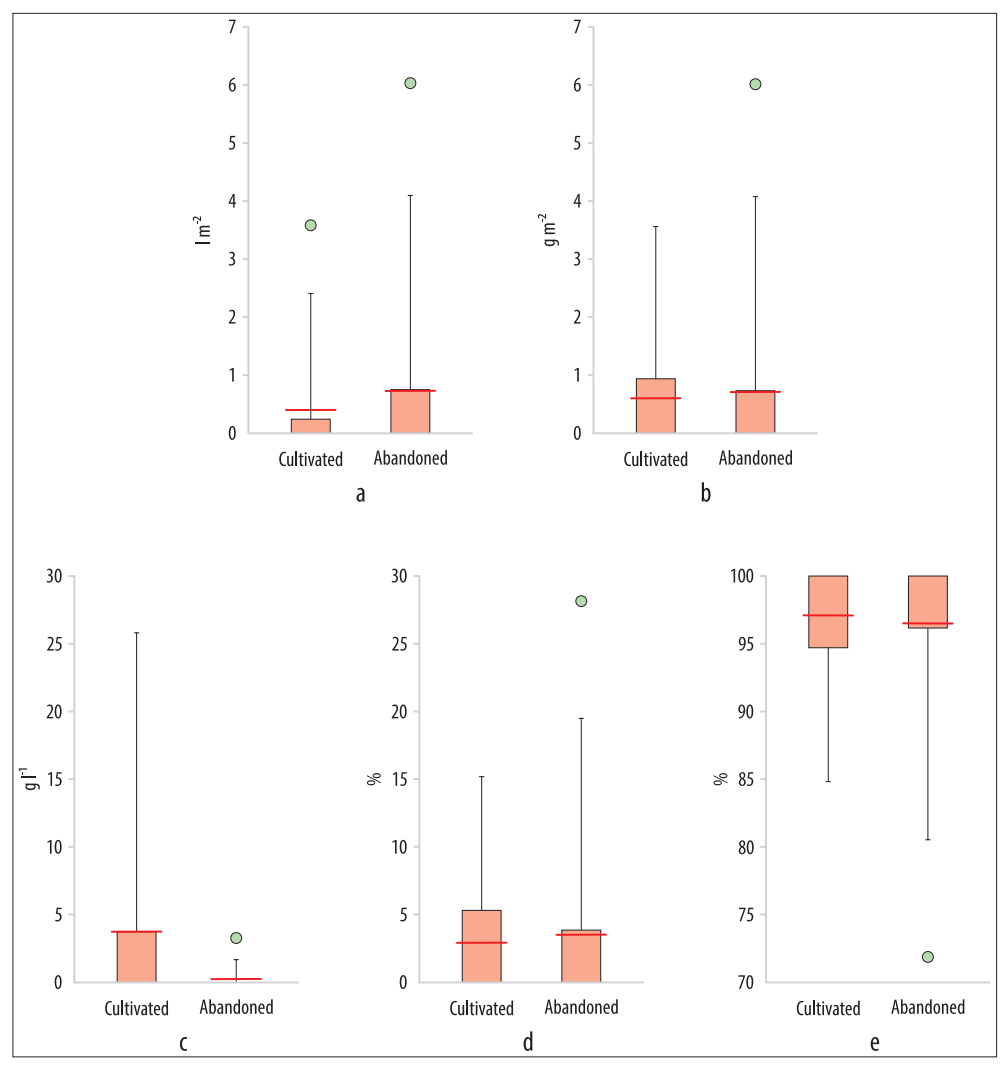

Fig. 4. Box plot of the soil erosion results in the cultivated and abandoned plots. $-\mathrm{a}=$ runoff; $\mathrm{b}=$ soil loss; $\mathrm{c}=$ sediment concentration; $\mathrm{d}=$ runoff coefficient; $\mathrm{e}=$ infiltration coefficient. Red dotted line represents the mean values.

In the vineyard, 56 per cent of the rainfall simulations do not obtain any runoff. On the other hand, in the abandoned field, a 71 per cent of the total experiments do not show water losses. In the cultivated plot, mean total runoff is $0.61 \mathrm{~m}^{2}$, reaching maximum values of $3.61 \mathrm{~m}^{2}$, meaning an average runoff coefficient of 3 per cent and maximums of 15 per cent. In the abandoned vine plantation, mean total runoff is $0.71 \mathrm{~m}^{2}$ and maximum values reach $61 \mathrm{~m}^{2}$. In terms of runoff coefficient, the abandoned plots show higher percentages, reaching mean values of 4 per cent and maximum amounts of 28 per cent.

These results confirm that after the abandonment and without a planned hillslope restoration, runoff can increase. These results are also coincident with other studied areas such as in the Mediterranean landscapes (LAsAntA, T. et al. 2015). However, Mediterranean authors claim that this fact is due to bare soils, a decrease in porosity and an increase in soil Calcium carbonate crusts as a consequence of the high temperatures, low organic content and calcareous parent material (Romero DíAz, A. et al. 2007; SEEGER, M. and RIES, J.B. 2008). In the studied vineyards, the main reason is that the vegetation cover, although very dense during winter and spring $(>100 \%)$, is eliminated by the owners to maintain clean roads and drainages. As a consequence, the vegetation does not have enough time to act as a useful protection during the rainiest season of the year. Moreover, as we observed in the soil profiles' description section, the sub-surface layers are 
strongly compacted in specific slope positions and the roots cannot develop a stable net. As a result, the infiltration capacity and water retention capacity could be reduced (BotTA, G.F. et al. 2012).

In the cultivated plot, mean total soil loss show values of about $4 \mathrm{~g} \mathrm{~m}^{2}$ and a maximum of $25.8 \mathrm{~g} \mathrm{~m}^{2}$. Our findings register a mean sediment concentration of $3 \mathrm{~g} \mathrm{l}^{-1}$ and a maximum of $7.8 \mathrm{~g} \mathrm{l}^{-1}$. In the abandoned vineyard, $1 \mathrm{~g} \mathrm{~m}^{2}$ and $13 \mathrm{~g} \mathrm{~m}^{2}$ are the mean and maximum soil loss values, respectively. Sediment concentration results in the abandoned vineyards are also lower than in the cultivated plots, reaching mean values of $0.3 \mathrm{~g} \mathrm{l}^{-1}$ and maximums of $3.3 \mathrm{~g} \mathrm{l}^{-1}$. These results confirm that the vineyards are more devoted to registering initial soil erosion processes than the abandoned plots, as other authors in several countries also registered (MARQues, M.J. et al. 2008; Chevigny, E. et al. 2014; Biddoccu, M. et al. 2017; Ben-SAlem, N. et al. 2018). However, it is important to remark that future research should be focused on studies over a long-term period to observe if they overpass tolerable soil erosion rates or not (Verheijen, F.G.A. et al. 2009).

Finally, in Table 4 and 5, Spearman rank's coefficients are applied to observe which environmental factor acts as driving factor of soil erosion. In the cultivated plot, we observed that there is a strong correlation between the runoff generation and soil loss, and sediment concentration. These results also coincide with other crops, where bare soils and steep slopes generate a parallel increase in water and soil losses such as in olives or citrus orchards (TAGUAs, E.V. et al.
2015; Jianjun, W. et al. 2017). As recently mentioned, it exists a high correlation between bare soils and an increase of vegetation cover, which not only protect against soil and water losses, but also enhance nutrients retention (OlmsteAd, M.A. et al. 2001; FourIE, J.C. et al. 2016) and biodiversity development (BARrio, I.C. et al. 2012; Lopes, C. et al. 2015) as well. On the other hand, we observe that in the abandoned plot, only a high correlation is found with sediment concentration and antecedent soil moisture. This result also confirms that: i) when soils are saturated, soil and water losses are also activated, responding to a Hortonian dynamic (Imeson, A.C. and LAveE, H. 1998; ZIEGLER, A.D. et al. 2007); and, ii) vegetation cover reduces soil erosion activation, but a non-planned hillslope restoration modifies the hydrological dynamic, making it difficult to predict the spatial intraplot variability.

\section{Conclusions}

This research pretends to demonstrate the significant changes in soil properties and initial soil erosion processes generated after vineyard's abandonment. In Figure 5, we represented our findings which demonstrated that: i) in vineyards, there are several differences in soil properties and soil profiles among slope positions due to tillage and trampling effects, showing clear marks, features of compaction and soil depletion in the footslopes; ii) also, in the cultivated field, we registered higher mean and maximum values of soil loss and sediment concentration data

Table 4. Spearman rank's coefficient in the cultivated vineyard

\begin{tabular}{l|c|c|c|c|c|c|c|c|c}
\hline Indicators & Runoff & $\begin{array}{c}\text { Soil } \\
\text { loss }\end{array}$ & SC & RC & Slope & VC & RFc & ASM & Roughness \\
\hline Runoff & - & $0.994^{*}$ & $0.982^{*}$ & $1.000^{*}$ & $0.536^{*}$ & $-0.765^{*}$ & $0.755^{*}$ & -0.152 & 0.126 \\
Soil loss & - & - & $0.994^{*}$ & $0.994^{*}$ & $0.531^{*}$ & $-0.755^{*}$ & $0.761^{*}$ & -0.126 & 0.105 \\
SC & - & - & - & $0.982^{*}$ & $0.549^{*}$ & $-0.739^{*}$ & $0.755^{*}$ & -0.121 & 0.110 \\
RC & - & - & - & - & $0.536^{*}$ & $-0.765^{*}$ & $0.755^{*}$ & -0.152 & 0.126 \\
\hline
\end{tabular}

Notes: SC = Sediment concentration; RC = Runoff coefficient; VC = Vegetation cover; RFc = Rock fragment covers; $\mathrm{ASM}=$ Antecedent soil moisture. ${ }^{*} \mathrm{p}<0.05$. 
Table 5. Spearman rank's coefficient in the abandoned vineyard

\begin{tabular}{l|c|c|c|c|c|c|c|c|c}
\hline Indicators & Runoff & $\begin{array}{c}\text { Soil } \\
\text { loss }\end{array}$ & SC & RC & Slope & VC & RFC & ASM & Roughness \\
\hline Runoff & - & $1.000^{*}$ & $0.854^{*}$ & $1.000^{*}$ & 0.270 & 0.048 & 0.134 & 0.369 & -0.102 \\
Soil loss & - & - & $0.854^{*}$ & $1.000^{*}$ & 0.270 & 0.048 & 0.134 & 0.369 & -0.102 \\
SC & - & - & - & $0.854^{*}$ & 0.381 & -0.064 & 0.114 & $0.517^{*}$ & 0.077 \\
RC & - & - & - & - & 0.270 & 0.048 & 0.134 & 0.369 & -0.102 \\
\hline
\end{tabular}

Notes: $\mathrm{SC}=$ Sediment concentration; $\mathrm{RC}=$ Runoff coefficient; $\mathrm{VC}=$ Vegetation cover $; \mathrm{RFC}=$ Rock fragment covers; $\mathrm{ASM}=$ Antecedent soil moisture. ${ }^{*} \mathrm{p}<0.05$.

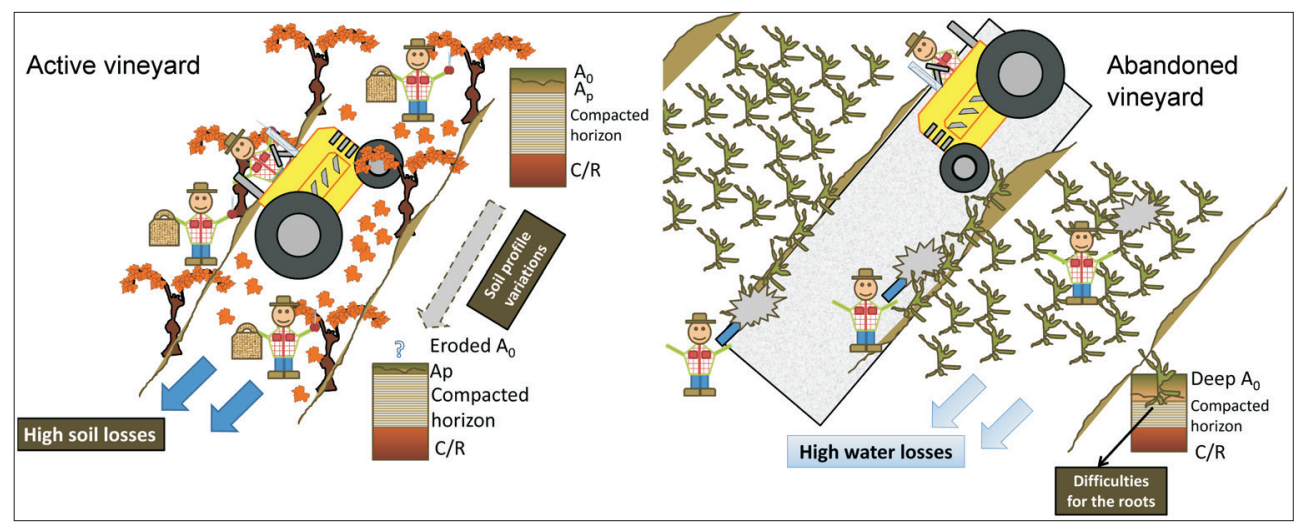

Fig. 5. Conclusions obtained from the cultivated and abandoned vineyards

than in the abandoned plot, being the vegetation cover and the steeper slopes the main driving factors; iii) on the contrary, in the abandoned plots a rapid homogenization of soil horizons and soil properties were found along the hillslope, where a deeper organic horizon was consistently developed on an underneath compacted and rocky horizon, which was developed during the cultivation phase; and, iv) due to high compaction and obstructed development of the roots, runoff and runoff coefficient were higher than in the cultivated plots.

Therefore, we claim that for the Central European vineyards under continental climate conditions, fortunately, at short-term periods, high facilities of a rapid recolonization and soil recuperation can be registered. However, any restoration plan that promotes a deep ploughing to remove the compacted sub-surface horizons and the prevention of annual pruning of vegetation after spring is not well suited for hillslope restoration and lessening soil and water losses.

\section{REFERENCES}

Arnáez, J., Ortigosa-Izquierdo, L.M., Ruiz-Flaño, P. and Lasanta, T.L. 2006. Distribución espacial del viñedo en la Comunidad Autónoma de La Rioja: influencia de la topografía y de las formas del relieve (Spatial distribution of the vineyards in the Autonomous Community La Rioja: the influence of the topography and relief). Polígonos: Revista de geografía 16. 11-34.

Balázs, B., Bíró, T., Dyke, G., Singh, S.K. and Szabó, S. 2018. Extracting water-related features using reflectance data and principal component analysis of Landsat images. Hydrological Sciences Journal 63. 269-284.

Barrio, I.C., Villlafuerte, R. and Tortosa, F.S. 2012. Can cover crops reduce rabbit-induced damages in vineyards in southern Spain? Wildlife Biology 18. 88-96. 
Ben-Salem, N., Álvarez, S., López-Vicente, M. 2018. Soil and water conservation in rainfed vineyards with common sainfoin and spontaneous vegetation under different ground conditions. Water 10(8) 1058. Doi:10.3390/w10081058

Biddoccu, M., Ferraris, S., Pitacco, A. and Cavallo, E. 2017. Temporal variability of soil management effects on soil hydrological properties, runoff and erosion at the field scale in a hillslope vineyard, North-West Italy. Soil and Tillage Research 165. 46-58.

Bienes, R., Marques, M.J., Sastre, B., García-Díaz, A. and Ruiz-Colmenero, M. 2016. Eleven years after shrub revegetation in semiarid eroded soils. Influence in soil properties. Geoderma 273. 106-114.

Bihari, Á. and Dezsô, Z. 2008. Examination of the effect of particle size on the radionuclide content of soils. Journal of Environmental Radioactivity 99. (7): 1083-1089.

Blavet, D., De Noni, G., Le Bissonnais, Y., Leonard, M., Maillo, L., Laurent, J.Y., Asseline, J., Leprun, J.C., Arshad, M.A. and Roose, E. 2009. Effect of land use and management on the early stages of soil water erosion in French Mediterranean vineyards. Soil and Tillage Research 106. 124-136.

Botta, G.F., Tolon-Becerra, A., Tourn, M., LastraBravo, X. and Rivero, D. 2012. Agricultural traffic: Motion resistance and soil compaction in relation to tractor design and different soil conditions. Soil and Tillage Research 120. 92-98.

Camps, J.O. and Ramos, M.C. 2012. Grape harvest and yield responses to inter-annual changes in temperature and precipitation in an area of north-east Spain with a Mediterranean climate. International Journal of Biometeorology 56. 853-864.

Certini, G., Campbell, C.D. and Edwards, A.C. 2004. Rock fragments in soil support a different microbial community from the fine earth. Soil Biology and Biochemistry 36. 1119-1128.

Chevigny, E., Quiquerez, A., Petit, C. and Curmi, P. 2014. Lithology, landscape structure and management practice changes: Key factors patterning vineyard soil erosion at metre-scale spatial resolution. Catena 121. 354-364.

DAviEs, B.E. 1974. Loss-on-Ignition as an estimate of soil organic Matter. Soil Science Society of America Journal 38. 150-151.

De Santisteban, L.M., Casalí, J. and López, J.J. 2006. Assessing soil erosion rates in cultivated areas of Navarre (Spain). Earth Surface Processes and Landforms 31. 487-506.

Follain, S., Ciampalini, R., Crabit, A., Coulouma, G. and Garnier, F. 2012. Effects of redistribution processes on rock fragment variability within a vineyard topsoil in Mediterranean France. Geomorphology 175-176. 45-53.

Fourie, J.C., Louw, P.J.E. and Agenbag, G.A. 2016. Cover Crop Management in a Sauvignon Blanc/ Ramsey Vineyard in the Semi-Arid Olifants River
Valley, South Africa. 2. Effect of different cover crops and cover crop management practices on grapevine performance. South African Journal of Enology and Viticulture 28. 81-91.

Galilea Salvador, I., Lasanta Martínez, T., ArnáezVAdillo, J. and Ortigosa, L.M. 2015. Evolución y desfragmentación del paisaje del viñedo en la Rioja alta (España) en el periodo 1956-2000 (Evolution and defragmentation of the vineyard landscapes in la Rioja alta [Spain] in the period 1956-2000). Boletín de la Asociación de Geógrafos Españoles 69. 315-331.

García-Díaz, A., Marqués, M.J., Sastre, B. and Bienes, R. 2017. Labile and stable soil organic carbon and physical improvements using groundcovers in vineyards from central Spain. The Science of the Total Environment 621. 387-397.

Imeson, A.C. and Lavee, H. 1998. Soil erosion and climate change: the transect approach and the influence of scale. Geomorphology 23. 219-227.

Iserloh, T., Fister, W., Seeger, M., Willger, H. RIES, J.B. 2012. A small portable rainfall simulator for reproducible experiments on soil erosion. Soil and Tillage Research 124. 131-137. https://doi. org/10.1016/j.still.2012.05.016

IUSS Working Group WRB 2006. Guidelines for constructing small-scale map legends using the WRB. $2^{\text {nd }}$ edition. Rome, FAO.

IUSS Working Group WRB 2014. World Reference Base for Soil Resources 2014. Rome, FAO.

JaKab, G., Hegyi, I., Fullen, M., Szabó, J., Zacháry, D. and SzalaI, Z. 2018. A 300-year record of sedimentation in a small tilled catena in Hungary based on $\delta 13 \mathrm{C}, \delta 15 \mathrm{~N}$, and C/N distribution. Journal of Soils Sediments 18. 1767-1779.

Jianjun, W., QuAnsheng, L. and LijiaO, Y. 2017. Effect of intercropping on soil erosion in young citrus plantation - a simulation study. Chinese Journal of Applied Ecology 8. 143-146.

JomaA, S., Barry, D.A., Brovelli, A., Heng, B.C.P., Sander, G.C., Parlange, J.-Y. and Rose, C.W. 2012. Rain splash soil erosion estimation in the presence of rock fragments. Catena 92. 38-48.

Khaledian, Y., Kiani, F., Ebrahimi, S., Brevik, E.C. and Aitkenhead-Peterson, J. 2017. Assessment and monitoring of soil degradation during land use change using multivariate analysis. Land Degradation and Development 28. 128-141.

Kinnell, P.I.A. 2016. A review of the design and operation of runoff and soil loss plots. Catena 145. 257-265.

Kou, M., JiaO, J., Yin, Q., Wang, N., Wang, Z., LI, Y., YU, W., WEI, Y., YAN, F. and CAO, B. 2016. Successional trajectory over 10 years of vegetation restoration of abandoned slope croplands in the Hill-Gully region of the Loess Plateau. Land Degradation and Development 27. 919-932.

Lasanta, T., Nadal-Romero, E. and Arnáez, J. 2015. Managing abandoned farmland to control the 
impact of re-vegetation on the environment. The state of the art in Europe. Environmental Science and Policy 52. 99-109.

Lesschen, J.P., Cammeraat, L.H. and Nieman, T. 2008. Erosion and terrace failure due to agricultural land abandonment in a semi-arid environment. Earth Surface Processes and Landforms 33. 1574-1584.

Lopes, C., Monteiro, A., Rückert, F.E., Gruber, B., SteinberG, B. and Schultz, H.R. 2015. Transpiration of grapevines and co-habitating cover crop and weed species in a vineyard. A "snapshot" at diurnal trends. VITIS - Journal of Grapevine Research 43. 111.

López-Vicente, M., QuiJano, L., Palazón, L., Gaspar, L. and Navas, A. 2015. Assessment of soil redistribution at catchment scale by coupling a soil erosion model and a sediment connectivity index (Central Spanish Pre-Pyrenees). Cuadernos de Investigación Geográfica 41. 127-147.

Marques, M.J., Bienes, R., Pérez-Rodríguez, R. and JiMÉNEZ, L. 2008. Soil degradation in central Spain due to sheet water erosion by low-intensity rainfall events. Earth Surface Processes and Landforms 33. 414-423.

Martínez-Casasnovas, J.A., Antón-Fernández, C. and Ramos, M.C. 2003. Sediment production in large gullies of the Mediterranean area (NE Spain) from high-resolution digital elevation models and geographical information systems analysis. Earth Surface Processes and Landforms 28. 443-456.

Martínez-Hernández, C., Rodrigo-Comino, J. and Romero-DíAz, A. 2017. Impact of lithology and soil properties on abandoned dryland terraces during the early stages of soil erosion by water in south-east Spain. Hydrological Processes 31. 3095-3109.

Morvan, X., Naisse, C., Malam Issa, O., Desprats, J.F., Combaud, A. and Cerdan, O. 2014. Effect of ground-cover type on surface runoff and subsequent soil erosion in Champagne vineyards in France. Soil Use and Management 30. 372-381.

Novák, T.J., Incze, J., Spohn, M., Glina, B. and Giani, L. 2014. Soil and vegetation transformation in abandoned vineyards of the Tokaj Nagy-Hill, Hungary. Catena 123. 88-98.

Novara, A., Keesstra, S., Cerdì, A., Pereira, P. and GristinA, L. 2016. Understanding the role of soil erosion on $\mathrm{CO}_{2}$-c loss using $13 \mathrm{c}$ isotopic signatures in abandoned Mediterranean agricultural land. Science of The Total Environment 550. 330-336.

Nyssen, J., Haile, M., Poesen, J., Deckers, J. and Moeyersons, J. 2001. Removal of rock fragments and its effect on soil loss and crop yield, Tigray, Ethiopia. Soil Use and Management 17. 179-187.

O.I.V. 2017. 2017 World vitiviniculture situation. Paris, International Organization of Vine and Wine.

Olmstead, M.A., Wample, R.L., Greene, S.L. and TARARA, J.M. 2001. Evaluation of Potential Cover Crops for Inland Pacific Northwest Vineyards. American Journal of Enology and Viticulture 52. 292-303.
Pahlavan-Rad, M.R. and Akbarimoghaddam, A. 2018. Spatial variability of soil texture fractions and $\mathrm{pH}$ in a flood plain (case study from eastern Iran). Catena 160. 275-281.

Poesen, J.W., van Wesemael, B., Bunte, K. and Benet, A.S. 1998. Variation of rock fragment cover and size along semiarid hillslopes: a case-study from southeast Spain. Geomorphology 23. 323-335.

Quiquerez, A., Chevigny, E., Allemand, P., Curmi, P., Petit, C. and Grandjean, P. 2014. Assessing the impact of soil surface characteristics on vineyard erosion from very high spatial resolution aerial images (Côte de Beaune, Burgundy, France). Catena 116. 163-172.

Richter, G. 1979. Bodenerosion in Rebanlagen des Moselgebietes. Ergebnisse quantitativer Untersuchungen 1974-1977. Trier, Forschungsstelle Bodenerosion der Universität Trier.

Ries, J.B., Seeger, M., Iserloh, T., Wistorf, S. and Fister, W. 2009. Calibration of simulated rainfall characteristics for the study of soil erosion on agricultural land. Soil and Tillage Research 106. 109-116.

Rodrigo Comino, J., Bogunovic, I., Mohajerani, H., Pereira, P., Cerdà, A., Ruiz Sinoga, J.D. and Ries, J.B. 2017. The impact of vineyard abandonment on soil properties and hydrological processes. Vadose Zone Journal 16. 12.

Rodrigo Comino, J., Iserloh, T., Morvan, X., Malam Issa, O., Naisse, C., Keesstra, S.D., Cerdà, A., Prosdocimi, M., Arnáez, J., Lasanta, T., Concepción Ramos, M., José Marqués, M., Ruiz Colmenero, M., Bienes, M., Ruiz Sinoga, J.D., Seeger, M. and RIES, B.J. 2016a. Soil erosion processes in European vineyards: A qualitative comparison of rainfall simulation measurements in Germany, Spain and France. Hydrology 3. (1): 6. https://doi.org/10.3390/ hydrology3010006

Rodrigo Comino. J., Quiquerez, A., Follain, S., Raclot, D., Le Bissonnais, Y., Casalí, J., Giménez, R., Cerdì, A., Keesstra, S.D., BreviK, E.C., Pereira, P., Senciales, J.M., Seeger, M.,Ruiz Sinoga, J.D. and RIEs, J.B. 2016b. Soil erosion in sloping vineyards assessed by using botanical indicators and sediment collectors in the Ruwer-Mosel valley. Agriculture, Ecosystems \& Environment 233. 158-170.

Rodrigo-Comino, J., Brings, C., Lassu, T., Iserloh, T., Senciales, J., Martínez Murillo, J., Ruiz Sinoga, J., SEEgER, M. and RIES, J. 2015. Rainfall and human activity impacts on soil losses and rill erosion in vineyards (Ruwer Valley, Germany). Solid Earth 6. 823-837.

Romero Díaz, A., Lasanta, T., Regües, D., LanaRenault, N. and Cerdì, A. 2011. Hydrological response and sediment production under different land cover in abandoned farmland fields in a Mediterranean mountain environment. Boletín de la Asociación de Geógrafos Españoles 55. 303-323.

Romero Díaz, A., Marín Sanleandro, P., Sánchez Soriano, A., Belmonte Serrato, F. and Faulkner, 
H. 2007. The causes of piping in a set of abandoned agricultural terraces in southeast Spain. Catena 69. 282-293.

Rosell, R.A., Gasparoni, J.C. and Galantini, J.A. 2001. Soil organic matter evaluation. In Assessment methods for soil carbon. Eds.: LAL, R., Kimble, J., Follet, R. and Stewart, B., US, Lewis Publishers, 311-322.

SALEH, A. 1993. Soil roughness measurement: Chain method. Journal of Soil and Water Conservation 48. 527-529.

SAMANi, A.N., Wasson, R.J., RAhDari, M.R. and Moeini, A. 2016. Quantifying eroding head cut detachment through flume experiments and hydraulic thresholds analysis. Environmental Earth Sciences 75. 14-24.

Seeger, M. and Ries, J.B. 2008. Soil degradation and soil surface process intensities on abandoned fields in Mediterranean mountain environments. Land Degradation and Development 19. 488-501.

Smith, P., Cotrufo, M.F., Rumpel, C., Paustian, K., Kuikman, P.J., Elliott, J.A., McDowell, R., Griffiths, R.I., Asakawa, S., Bustamante, M., House, J.I., Sobocká, J., Harper, R., PAN, G., West, P.C., Gerber, J.S., Clark, J.M., Adhya, T., Scholes, R.J. and Scholes, M.C. 2015. Biogeochemical cycles and biodiversity as key drivers of ecosystem services provided by soils. SOIL 1. 665-685.
Szabó, J., JАкав, G. and Szabó, B. 2015. Spatial and temporal heterogeneity of runoff and soil loss dynamics under simulated rainfall. Hungarian Geographical Bulletin 64. (1): 25-34.

Szalai, Z., Szabó, J., Kovács, J., Mészáros, E., Albert, G., Centeri, Cs., Szabó, B., Madarász, B., Zacháry, D. and JАКАB, G. 2016. Redistribution of soil organic carbon triggered by erosion at field scale under subhumid climate, Hungary. Pedosphere 26. 652-665.

Taguas, E.V., Guzmán, E., Guzmán, G., Vanwalleghem, T. and Gómez, J.A. 2015. Characteristics and importance of rill and gully erosion: a case study in a small catchment of a marginal olive grove. Cuadernos de Investigación Geográfica 41. 107-126.

Verheijen, F.G.A., Jones, R.J.A., Rickson, R.J. and Sмiтh, C.J. 2009. Tolerable versus actual soil erosion rates in Europe. Earth-Science Reviews 94. 23-38.

Zavala, L.M., Jordán, A., Bellinfante, N. and Gil, J. 2010. Relationships between rock fragment cover and soil hydrological response in a Mediterranean environment. Soil Science and Plant Nutrition 56. 95-104.

Ziegler, A.D., Giambelluca, T.W., Plondke, D., Leisz, S., Tran, L.T., Fox, J., Nullet, M.A., Vogler, J.B., Minh Troung, D. and Vien, T.D. 2007. Hydrological consequences of landscape fragmentation in mountainous northern Vietnam: Buffering of Hortonian overland flow. Journal of Hydrology 337. 52-67. 